\title{
Bartłomiej Biegajło \\ Czytając między wierszami. Rodzinna Europa Czesława Miłosza i jej angielski/amerykański przekład
}

\begin{abstract}
Biegajło Bartłomiej, Czytając między wierszami. "Rodzinna Europa” Czesława Miłosza $i$ jej angielski/amerykański przekład [Reading between the lines. Czesław Miłosz's Native Realm. A Search for Self-Definition and its English/American translation]. "Przestrzenie Teorii" 15. Poznań 2011, Adam Mickiewicz University Press, pp. 111-124. ISBN 978-83-232-2293-4. ISSN 1644-6763.
\end{abstract}

The aim of this article is to discuss the problem of translating Polish prose, based on an analysis of a selection of samples taken from Czesław Miłosz's Native Realm. A Search for Self-Definition translated by Catherine S. Leach. The book documents specific relations between the Western and the Eastern Europe determined by historical provenance of the realms in question. The dichotomy of the collective European history has a profound influence on the reception of Polish literature among the Western audience. Native Realm showcases the issue perfectly - it is interesting in terms of its careful account of the historical and social development of the Continent. The perception of reality is conditioned by an inherent dissimilarity of experiences between the West and the East. The intention of Miłosz was to provide an analysis of them and produce an insightful book addressed specifically to the Western readership. My discussion is an attempt to prove that the endeavour is doomed to failure due to the intrinsic differences between the cultures involved, as cultural inheritance determines the interpretation of historical facts and prompts dissimilar connotations. In the case of Native Realm, on the one hand, we encounter Miłosz's vision/imagination that is irreversibly rooted in the Slavic way of looking at things and, on the other, the distinctively dissimilar Western vantage point. Translating these differences appears to be a major challenge for any translator.

Świat literatury bardzo często traktowany jest jako obszar zdefiniowany konwencjonalnymi ramami czasowymi, a co się z tym wiąże, zestawem regularnych cech i właściwości, które pozwalają nam, czytelnikom, poruszać się w meandrach nakładających się na siebie epok czy to literackich, czy historycznych. Niewątpliwie taka percepcja literatury ułatwia stosunkowo jasną chronologizację wydarzeń na przestrzeni wielowiekowej tradycji literackiej, jednakże warto również odnotować oczywistą zależność na linii autor - dzieło - epoka literacka. Relacje te, podyktowane umownymi granicami czasowymi danej epoki, niejednokrotnie stanowią o wyjątkowości pary dzieło-autor. Wzrost zainteresowania autorem $\mathrm{w}$ wielu sytuacjach wynika $\mathrm{z}$ doraźnych trendów nakierowanych na daną epokę literacką, w efekcie czego rośnie liczba publikacji na temat autorów piszących $\mathrm{w}$ tej właśnie epoce. Wielu z nich jest jednak niesłusznie sta- 
wianych w roli piewców idei lub wartości charakterystycznych dla epoki, w której przyszło im funkcjonować. Ramy chronologiczne determinują, lub jak kto woli, zakłócają odbiór literackiego dzieła, a zatem wywierają doniosły wpływ na stosunek do autora. Relację odwrotnie proporcjonalną można dostrzec w przypadku naszego polskiego noblisty - Czesława Miłosza, który uważany jest za „najdoskonalsze w poezji polskiej spełnienie Kanonu klasycznego a także mrocznego nurtu k[anonu] romantycznego"1. Miłosz uosabia polskiego inteligenta zakochanego w klasyce, czerpiącego z niej prawdę, lecz także odwieczne polskie błogosławieństwo/przekleństwo spuścizny romantycznej obecnej w sferze literatury czy też, o wiele bardziej istotnej i mającej zasadniczy wpływ na wymienioną, sferze historycznej. Niedoceniany w ojczystym kraju, często nazywany banitą, dziś Miłosz jest literacką instytucją wymykającą się sztywnym schematom kategoryzacji, którego talent, wiedza i pracowitość zostały rozpoznane i zwieńczone przyznaniem mu prestiżowej Nagrody Nobla. Dzięki niej autor zyskał potężne narzędzie w postaci sławy i od tej pory jego głos stał się donośny, słyszalny i rozpoznawalny w najdalszych zakątkach świata. Niniejszy artykuł ma na celu wykrycie prawdopodobnych różnic w zakresie recepcji polskiej prozy na przykładzie wydanej w 1959 roku Rodzinnej Europy Czesława Miłosza.

Rodzinna Europa jest tekstem zamykajacym w sobie pewien rodzaj doświadczeń, które Czesław Miłosz wielokrotnie podejmował na kartach swych utworów. Książka ta zatem jest jedną z wielu prób rozwikłania nienaruszalnych od lat stosunków panujących na linii Wschód - Zachód:

Terminami Wschodu i Zachodu posługujemy się zazwyczaj w sensie geograficznym dla oznaczenia kierunków czy też stron świata i ta powszechnie stosowana praktyka nie budzi w nas najmniejszych wątpliwości. Trudności pojawiają się wówczas, gdy abstrahując od kryterium ściśle geograficznego traktujemy Wschód i Zachód jako synonimy odrębnych kręgów cywilizacyjno-kulturowych, ekonomicznych, społecznych, politycznych czy też jako swoiste wyznaczniki różnych etapów lub faz historii powszechnej².

Przytoczone słowa definiują świat w koncepcji dychotomicznych relacji, nazywanych umownie na potrzeby tego tekstu „bipolarnymi przestrzeniami”. W ramach tych przestrzeni znajdziemy wszystkie wymienione przez Wierzbickiego kręgi charakteryzujące Wschód i Zachód, które, jako „bipolarne przestrzenie”, stoją w elementarnej opozycji w stosunku do siebie. Zatem różnice między Wschodem a Zachodem ukształtowane są na podstawie historycznie uwarunkowanych antagonizmów.

1 Z. Herbert, C. Miłosz, Korespondencja, Zeszyty Literackie, Warszawa 2006, s. 142.

2 A. Wierzbicki, Wschód-Zachód w koncepcjach dziejów Polski, Państwowy Instytut Wydawniczy, Warszawa 1984, s. 5. 
Zgodnie z powyższym, wyciągnąć można wniosek, będący głęboko zakorzeniony w mentalności europejskiej, że nie jest to rodzaj odmienności konstruktywnej, mobilizującej strony do podnoszenia swego statusu na arenie międzynarodowej, rodzaj wzajemnego współzawodnictwa w wyścigu o ostateczną supremację. W toku dziejów „bipolarne przestrzenie” wykrystalizowały model relacji Wschód - Zachód, który z powodzeniem precyzuje Miłosz w „Przypisie po latach” do wydanej w 2001 roku reedycji Rodzinnej Europy:

Przystępując do pisania Rodzinnej Europy, jeszcze silniej niż w poprzednich książkach chciałem zaznaczyć mój sprzeciw wobec ich kręgu kulturalnego. Dlaczego przecinali Europę na dwie części i nas wrzucali w „ciemności zewnętrzne”, gdzie nawet jeżeli następujące po sobie polityczne systemy miały złe strony, to były dostatecznie dobre dla barbarzyńców?3.

Trwały podział na potężny i ekonomicznie niezależny Zachód oraz barbarzyński Wschód stał się przez lata aksjomatyczną wykładnią stosunków międzynarodowych między tymi częściami świata. Jednakże Rodzinna Europa proponuje zgoła odmienne spojrzenie na tę problematykę. Przyjrzyjmy się tytułowi analizowanej książki. Miłosz, wręcz z premedytacją, już w tytule umieszcza przymiotnik „rodzinny” - jasna i bezpośrednia aluzja, wyjaśniająca niemalże zdawkowo motywy powstania książki. Wyraz ten wywołuje przede wszystkim pozytywne konotacje i polski czytelnik praktycznie nie jest w stanie odczytać go w żaden inny sposób. W skład pola semantycznego przymiotnika „rodzinny” mogą wchodzić: dobro, harmonia, współistnienie, zupełna ufność pozostałym członkom „rodziny” i taka również jest percepcja Europy widziana oczami Miłosza. Już pierwsze strony książki dowodzą intencji autora, który jawnie stwierdza, że „pierwszym ziarnem była chęć, żeby przybliżyć Europę Europejczykom"4 i w pewnym znaczeniu odkryć ją na nowo. Miłosz uzupełnia, wyznając:

Postanowiłem więc napisać książkę o Europejczyku wschodnim, urodzonym mniej więcej wtedy, kiedy tłumy Paryża i Londynu wiwatowały na cześć pierwszych lotników; o człowieku, który mniej niż ktokolwiek mieści się w stereotypowych pojęciach niemieckiego porządku i rosyjskiej ame slave ${ }^{5}$.

Zatem Rodzinna Europa zyskuje wydźwięk ponadczasowy, bowiem autor pragnie scalić dzieje wschodniej Europy z ekonomicznie wyprzedza-

${ }^{3}$ C. Miłosz, Rodzinna Europa, Wydawnictwo Literackie, Kraków 1959/2001, s. 6. W dalszej części artykułu powołuję się na reedycję Rodzinnej Europy wydanej w 2001 roku przez wydawnictwo Biblioteka Polityki.

${ }^{4}$ C. Miłosz, Rodzinna Europa, dz. cyt., s. 12.

5 Tamże. 
jącą ją Europą Zachodnią, jednocześnie zdając sobie sprawę, że „takie przedsięwzięcie jest niewdzięczne, bo skłonność do ogólnych, choć niesprawdzonych idei jest w nas mocno ugruntowana"6. Miłosz jednak niezłomnie dąży do zdewaluowania mitu wyjątkowości Zachodu i jawi się jako autor poszukujący wspólnych korzeni kontynentu europejskiego. Warto zaznaczyć, że rok pierwszego wydania Rodzinnej Europy zbiegł się z wstępnymi widocznymi symptomami zimnej wojny prowadzonej między USA a ówczesnym ZSRR. Uznawana za nowy rodzaj konfliktu zimna wojna objawiała dwa główne oblicza świata: kapitalizm i komunizm. Lata sześćdziesiąte to ciągła, agresywna walka ideologiczna między politycznymi reżimami, której rzeczywistym i dla zwykłych ludzi najistotniejszym przejawem były warunki ekonomiczne, w jakich ludność zmuszona była funkcjonować. Przyszłość zweryfikowała założenia obu systemów, jednak, co ważniejsze, utrwaliła absurdalny podział na Wschód i Zachód, tym bardziej niebezpieczny, bo usankcjonowany już nie tylko ekonomicznymi różnicami, ale fundamentalnie skrajnymi ideologiami. Miłosz, świadomy drastycznych sprzeczności między „dwiema Europami”, nie zamierza ich uwydatniać, lecz usiłuje zlokalizować wspólne cechy Europejczyków i stąd tytuł książki Rodzinna Europa.

Podejmowanie tematów kontrowersyjnych, a takim jest próba gruntownej rewizji kolektywnej mentalności europejskiej, wiąże się z zachowaniem możliwie jak największej obiektywności pisarza, ale nie tylko, bowiem „nie tylko czytelnik, ale sam autor, starając się zobiektywizować cechy krajów i narodów, waha się pomiędzy uproszczeniem i wielostronnością prawdy"'. Powyższe wyznanie weryfikuje stopień subtelności przedsięwzięcia, ale także dowodzi, że Miłosz jest unikalnej natury subtelnym obserwatorem świata.

Rodzinna Europa opisuje wiele istotnych wydarzeń historycznych i stanowią one kanwę publikacji, jednak, aby w pełni zrozumieć cel i założenia książki, nieodzowna jest dokładna lektura fragmentów dokumentujących powstanie i rozwój rodzinnej dla Miłosza Litwy. Zamiłowania autora nie ograniczają się jednakże wyłącznie do historii, gdyż jego dociekania „często prowadzą [go] na pogranicze antropologii, historii i socjologii”, ale jak sam przyznaje „bez wygórowanych ambicji wiedzy”. Czytelnik, który spotyka tego typu stwierdzenie, może, de facto, czuć się zaproszony do podjęcia wysiłku przyłączenia się do wielkiej „eksploracji, wyprawy w głąb własnej, jednak nie tylko własnej, przeszłości”10. Miłosz

6 Tamże, s. 13.

7 Tamże.

8 Tamże.

9 Tamże.

10 Tamże. 
zaprasza nas do spojrzenia w przeszłość, lecz bez rewizjonistycznych aspiracji, próbuje autor raczej zjednoczyć Europę, natchnąć nowym, kolektywnym obliczem, „gdzie łączy się w jedno kronika wypadków i moda, zmiany opinii i wierzeń" 11 , to wszystko, co w istocie stanowi o europejskiej wspólnocie, znanej nam dzisiaj pod postacią usilnych dążeń do utworzenia jednolitego ciała politycznego - Unii Europejskiej. Czytając Rodzinna Europę, z każdą następną stroną zaczynamy dojrzewać do jednoczących argumentów Miłosza, jednakże mentalność zarówno czytelników, jak i samego autora stawia poważne przeszkody jasnemu udokumentowaniu wspólnej przeszłości Europy. Odwieczna silna polaryzacja kontynentu wywarła olbrzymi wpływ na sposób postrzegania świata, w efekcie czego przyswajamy wnioski Miłosza, by po chwili skonfrontować je z osobistymi doświadczeniami i natychmiast uznać wyższość subiektywnej opinii. Miłosz jednak konsekwentnie kroczy wytyczoną przez siebie ścieżką i aby zminimalizować stopień subiektywizacji, a także podnieść swoją wiarygodność, decyduje się na umieszczenie losów swego życia i swojej rodziny jako punkt wyjścia do wszelkich komentarzy natury generalnej.

Czytelnik jest zatem prowadzony przez Miłosza korytarzami swego życia, autor nie ma nic do ukrycia, dzieli się z czytelnikiem każdym detalem rodzinnej historii, w efekcie czego poznajemy Miłosza poszukującego swych najdalszych przodków, jakby „przy okazji” odkrywającego liczne fakty, wyciągając wnioski interesujące nie tylko dla czytelnika zachodnioeuropejskiego, dla którego Rodzinna Europa jest przeznaczona, ale również czytelnik rodzimy może być zaskoczony wieloma obserwacjami poczynionymi przez autora. Nasza uwaga, w wiele mówiącym pierwszym rozdziale książki pt. Miejsce urodzenia, kierowana jest zatem aż do czasów Imperium Rzymskiego:

W ciągu wielu wieków, kiedy nad Morzem Śródziemnym powstawały i upadały królestwa, a niezliczone generacje przekazywały sobie wyrafinowane rozrywki i grzechy, mój kraj rodzinny był puszczą, odwiedzaną na brzegach tylko przez okręty wikingów. Położony był poza zasięgiem map i należał do baśni ${ }^{12}$.

Miłosz, jakby na przekór intencjom książki, podkreśla swoistą dzikość, czy też dziewiczość krainy, z której się wywodzi i jest to wyobrażenie, jakie Europa Zachodnia pielęgnuje od tysięcy lat. Wschód, w przywoływanych czasach, stanowi miejsce puste, odległe, nieznane i niezamieszkane - w tej sytuacji Zachód przyjmuje naturalną rolę wyznacznika czasu, poziomu zaawansowania, zarówno technicznego, jak i duchowego. Miłosz dostrzega tę zależność i ustosunkowuje się do niej bezpośrednio,

11 Tamże.

12 Tamże, s. 17. 
wyznając: „skoro umysły zaprzątało wtedy szerzenie prawdziwej wiary, a walka $\mathrm{z}$ niewiernymi była głównym tematem rycerskiej pieśni i legendy, [...] mieszkańcy nadbałtyckich lasów stali się skandalem dla chrześcijaństwa"13. Autor jasno stwierdza, że to epoka średniowiecza zapoczątkowała prawdziwy podział Europy, co więcej, obwinia o to religię, czy też raczej wyznawców chrześcijaństwa zapatrzonych w swoją wizję duchowości, siłą narzucaną „barbarzyńcom” 14 w dobie średniowiecznych wypraw krzyżowych. Europa w tym okresie poniosła dotkliwe straty w sferze zbiorowej mentalności, udokumentowane są bowiem „sposoby”, z których krzyżowcy korzystali, nawracając „niewiernych”, a ich proweniencja dyskusyjna - napaści, grabieże, morderstwa, by wymienić kilka. Opisywane wydarzenia miały miejsce setki lat temu, jednak jak dowodzi Miłosz: „walka z ostatnimi poganami w Europie przechowała się w świadomości zbiorowej, co prawda w formie mglistej, jednak dostatecznie silnie, żeby figurować nawet $\mathrm{w}$ niektórych katechizmach katolickich naszych czasów"15.

Powyższe częściowo wyjaśnia powód umiejscowienia Europy Wschodniej w „ciemnościach zewnętrznych”16, z których właściwie do dnia dzisiejszego nie jest $\mathrm{w}$ stanie się wydostać. W świetle dotychczasowej dyskusji dramatyczne wydaje się, iż „najbardziej nawet zamierzchłe tragedie mają wielką trwałość, bo żyją w przysłowiu, w pieśni ludowej, w podaniu przekazywanym z ust do ust i później stanowią gotowy materiał literatury"17. Miłosz zdecydowanie oponuje wizji Europy podzielonej religijną dyskryminacją ${ }^{18}$, ale także brakiem równowagi w zakresie polityki, ekonomii i ideologii. Jednakowoż jest to Rodzinna Europa scementowana wspólną spuścizną kulturalną i historyczną.

W amerykańskiej edycji Rodzinnej Europy, wydanej po raz pierwszy w roku 1968, a w Wielkiej Brytanii dopiero w 1981, zaobserwować można pewną nieścisłość tłumaczeniową w stosunku do zamierzeń autora książki. Tekst został przełożony przez Catherine S. Leach i trzeba wyraźnie podkreślić, że jest to tłumaczenie bardzo poprawne. Wątpliwości budzi jednak tytuł: Native Realm. A Search for Self-Definition. Angielskie wyrażenie native realm nie może być traktowane jako ekwiwalent polskiego rodzinny, gdyż, semantycznie rzecz ujmując, wywołuje zupełnie odmien-

13 Tamże.

14 Tamże, s. 6.

15 Tamże, s. 18

16 Tamże, s. 6.

17 Tamże, s. 18.

18 Notabene, dziś sytuacja wydaje się odwrócona - to Zachód jest uważany za barbarzyńców (zsekularyzowanie), a szeroko rozumiany Wschód to ortodoksyjny piewca religijnych wartości i obrońca tradycji. 
ne konotacje. Native to słowo rzeczywiście często używane w odniesieniu do rdzennego obszaru, czy to z punktu widzenia geograficznego, czy też formacji państwowej i w takim rozumieniu może stanowić wskazówkę wyjaśniającą motywy zastosowania tej frazy przez tłumaczkę, jednak jego konotacje bliższe są raczej poczuciu nacjonalizmu niż rodzinności i harmonii. Tłumaczenie tytułu zakłóca odbiór całości tekstu i już na wstępie determinuje sposób, w jaki anglojęzyczny czytelnik będzie odczytywał treści zawarte w Rodzinnej Europie. Podtytuł, którego notabene nie ma w wersji oryginalnej, zdaje się potwierdzać te obawy: A Search for Self-Definition implikuje próbę odszukania swego ,ja”, zdefiniowanie swej przynależności kulturowej, politycznej, światopoglądowej itd. Takie potraktowanie tematu znacznie rozmija się z dyskutowanymi tu założeniami Miłosza, bowiem diametralnej zmianie ulega sens książki - czytelnik tłumaczenia instynktownie szuka odmienności, egzotyki, o jakie nietrudno, zważywszy na fakt pochodzenia autora. Tłumaczka zatem (nie)świadomie potęguje poczucie wyobcowania „dwóch Europ” - elementarny problem, którego eksplikacja zmotywowała Miłosza do napisania Rodzinnej Europy.

Czytając Rodzinna Europę, nie sposób nie zaobserwować reguły, którą Miłosz stosuje z premedytacją, mianowicie, wszelkie konkluzje głoszone $\mathrm{w}$ książce, poprzedzone są opisem lub odniesieniem do wybranego zjawiska historycznego. Autor traktuje historię jako punkt odniesienia do dyskusji i historię należy tu rozumieć jako historię państw, ustrojów, ale również historię osobistą, rodzinną. Miłosz odznacza się wyjątkową powściągliwością w przytaczaniu i komentowaniu faktów historycznych, świadomy jest bowiem inherentnej ludzkiej pokusy wykorzystania ich do manipulacji odbiorcy. Autor wyjaśnia: „historia, jeśli nie można jej ożywić przez coś, co ma dla nas osobiste zabarwienie, będzie zawsze mniej albo bardziej abstrakcyjna, wypełnią ją starcia anonimowych sił i schematy"19. Miłosz staje w obronie historii i pełny temu wyraz daje w eseju pt. $L a$ Combe w tomiku zatytułowanym Zaczynajac od moich ulic:

Historia. Historycyzm. Historicite. Rzecz jednak w tym, że ile razy nasi współcześni próbują dotknąć tej niesamowitej istoty, która im się w swoim majestacie ukazała, są skazani na bryki. Inaczej ani rusz, nie mogą uchwycić „wielkich linii”, wpadają w popłoch, są bezradni. Za duży materiał. Oni chcą historię rozumieć (a demon z rykiem śmiechu podpowiada: i nad nią panować) ${ }^{20}$.

Opierając się na historii, Miłosz jednocześnie eksponuje swoje rozczarowanie, by nie powiedzieć oburzenie, co do sposobu, w jaki jest ona trak-

19 C. Miłosz, Rodzinna Europa, dz. cyt., s. 28.

${ }^{20}$ Tegoż, Zaczynając od moich ulic, Wydawnictwo Śląskie, Wrocław 1990, s. 239. 
towana przez badaczy, którzy „mogą z niej zrozumieć tyle tylko, ile uczeń, który nie przeczytał ani jednego wiersza jakiegoś poety i nauczył się ze ściągaczki" 21 . Autor przeciwstawia się wyrywkowemu stosunkowi do historii, który musi prowadzić do wielu uproszczonych konkluzji, „chodzi [...] o fałsz skróconych dziejów w książce dla dzieci”22. Przestrzega Miłosz, że dyskusja o historii to „samotność i poczucie, że ten moment dziejowy jest jedyny i że szamocząc się $\mathrm{z}$ jego problematyką nigdzie $\mathrm{w}$ przeszłości nie znajdzie się oparcia”23, dlatego też nasza „uwaga kieruje się w przyszłość, z nadzieją albo z paniką"24.

Podjęcie tematu podziału Europy na Wschód i Zachód nie może się odbyć bez ciągłego odniesienia do historii, jest ona permanentną siłą koordynującą te relacje. Jednak, aby umknąć nieświadomemu uproszczeniu tej dyskusji, Miłosz świadomie skupia się na bogatej tradycji ludowej Słowiańszczyzny. Ponadto, decyduje się na wysunięcie dziejów swej rodziny na pierwszy plan: ,jeśli wspominam o moich przodkach, to dlatego, że są oni dla mnie siłą. Dzięki nim mogę dotknąć dawnych strojów, mebli, pisma na pożółkłych dokumentach jako rzeczy niezupełnie dla mnie martwych"25. Zatem pewien stopień ekshibicjonizmu uprawnia Miłosza do podjęcia dialogu z historią, pozwala on na „intuicję historyczną, która jest chyba niemożliwa, jeżeli brak punktu odniesienia"26. Mamy więc książkę dokumentującą historię rodziny Miłoszów, ale także bogatą w opisy rodzinnych stron autora. Są to krajobrazy, które natura obdarzyła szczególną hojnością i jak wyznaje Miłosz: „dla kogoś, kto dotyka przeszłości i karmi nią chwilę, czy ma w sobie Karpaty czy Wielkie Księstwo Sabaudii albo Litwy, czy Afrykę - a słuszniej powiedzieć, że jeżeli ma jedno z tego, ma wszystko"27, ponieważ „cokolwiek go otacza, jest albo naturą, albo jest ludzkie, a przez to zawsze ciekawe i podniecające"28. Przytoczone słowa warunkują ogromny respekt i miłość zarówno do natury, jak i jej swoistego „przedłużenia” w postaci ludowej tradycji czy też lokalnych anegdot. Wyjaśnia także olbrzymi szacunek pisarza do Williama Faulknera, który „swoje dzieło umieścił i w nurcie czasu, i w ramach jednego powiatu nad Missisipi"29, czego efektem jest analizowana tu Rodzinna Europa, ale także Dolina Issy, stanowiące testament ludowego bogactwa Słowiańszczyzny.

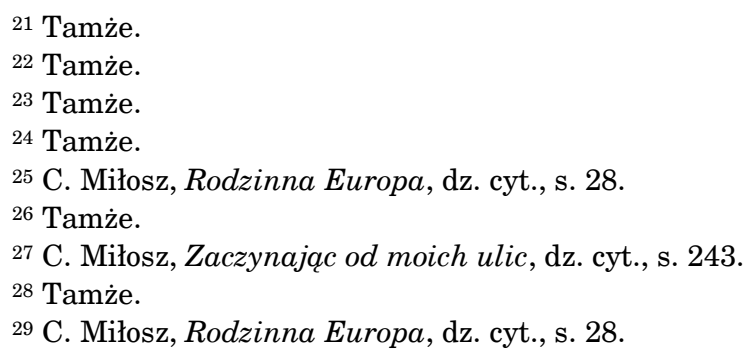


Przywołanie Faulknera nie jest przypadkowe i obrazuje naturę problemu angielskiego przekładu Rodzinnej Europy. Miłosz zaznacza, że „atmosfera jego książek jest znacznie nam bliższa niż atmosfera książek Balzaka czy Zoli”30, toteż spodziewać się należy odmiennych oczekiwań literackich w przypadku polskiego czytelnika w porównaniu do, ujmijmy to ogólnie, zachodnioeuropejskiego. Powyższe konstytuuje istotny czynnik wpływający na recepcję literatury, czego wyraźnym dowodem jest $R o$ dzinna Europa.

Dotychczasowe rozważania próbowały przybliżyć zasięg problemów prezentowanych przez Czesława Miłosza. Spróbujmy zatem przeanalizować wybrane fragmenty tekstu w perspektywie ich recepcji w dwóch różnych kręgach kulturowych - polskim i anglojęzycznym. Przytoczony niżej fragment pochodzi z pierwszego rozdziału Rodzinnej Europy pt. Miejsce urodzenia:

Na wsi mówiono po litewsku i częściowo po polsku. Miasteczko, dokąd wożono płody rolne na sprzedaż, używało na co dzień polskiego i jidysz. Ale już żandarm wlokący za sobą długą szaszkę, poborca podatków, konduktor na kolei, importowani dla celów administracji, zwracali się do tubylców po rosyjsku, wychodząc z założenia, że każdy musi rozumieć język urzędowy. A wyżej była piramida rosyjskich szkół i uniwersytetów, biur, ministerstw, państwowej religii, prawosławia, a na szczycie tron cara ${ }^{31}$.

Opis ten, pomijając wiele asocjacji nasuwających się po jego lekturze, ilustruje przede wszystkim bogactwo narodowości zamieszkujących tereny litewskie. Litwa, która wychowała Miłosza, była obszarem zamieszkanym przez rodzimą ludność wymieszaną $\mathrm{z}$ Polakami, Rosjanami i Żydami, a każda z tych nacji charakteryzowała się silnym poczuciem narodowej tożsamości. Taka była ówczesna rzeczywistość, jaką autor usiłuje okiełznać w jednym ze swych szkiców zatytułowanym po prostu $R z e$ czywistość: „rzeczywistość [...] w której ludzie-rzeczy wykonują rozkazy podyktowane przez innych ludzi, niby panów własnego i cudzego losu, ale naprawdę zmienionych w rzeczy przez tzw. konieczności życiowe" 32 . Był to zatem swoisty tygiel narodowościowy, a „za nim rozpościerała się przeszłość krwawych bitew, rozpaczliwych powstań, szubienic, zesłań na Sybir i kształtowała całe późniejsze życie" 33 . Historyczna proweniencja polskiego czytelnika powoduje tu jednak serię skojarzeń, $\mathrm{z}$ pewnością niewidocznych dla czytelników tłumaczenia, wyjąwszy slawistów czy osoby szczególnie zainteresowane tematem. Przyjrzyjmy się wobec tego tłumaczeniu zacytowanego fragmentu:

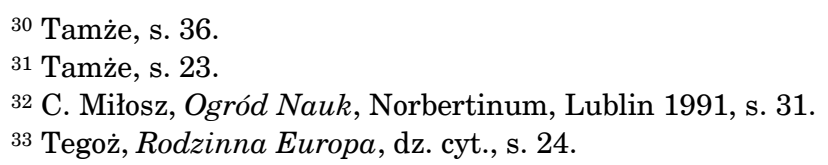


In the country, Lithuanian and some Polish were spoken. The little town, where crops were brought to market, used Polish and Yiddish for everyday. But all the officials imported for administrative purposes - the military gendarme trailing his long, clumsy saber behind him, the tax collector, the train conductor addressed the local population in Russian, on the ground that everyone had to understand the official language. On a higher level, there were Russian schools and universities, offices, ministries, the state religion (Orthodoxy), and at the very top of the pyramid - the throne of the $\mathrm{Czar}^{34}$.

Tekst przedstawia cztery nacje, których nazwy funkcjonują metonimicznie. Wspomnienie Polski i Litwy w kontekście Rosji powoduje zdecydowanie pozytywne reakcje lub co najmniej neutralne. Historia odnotowała rok 1569, kiedy powstała Rzeczpospolita Obojga Narodów, czyli nastąpiło zjednoczenie Królestwa Polskiego i Wielkiego Księstwa Litewskiego. Unia między tymi krajami trwała ponad 200 lat i w owym czasie stanowiła istotną siłę polityczną na arenie międzynarodowej, przy czym nieobce były jej aspiracje imperialne. Dziś, z perspektywy czasu, przy niewielkiej roli odgrywanej w Europie zarówno przez Polskę, jak i Litwę ${ }^{35}$, wspomnienie ówczesnej potęgi wydaje się ostatnią deską ratunku.

Opisane asocjacje zdają się balsamować wszelkie skojarzenia związane z Rosją, które kolektywnie są niemal wyłącznie negatywne. Publikacje dokumentujące rozbiory, zsyłki na Sybir, rusyfikację szkolnictwa itd. są powszechnie dostępne i fakty te ciągle stanowią żywą ranę w pamięci wielu. Warto w tym miejscu przytoczyć niezmiernie interesujące komentarze zamieszczone przez Dariusza Pawelca w przedmowie do Zniewolonego Umystu. We wstępie pt. „Zniewolony Umysł” jako parabola Pawelec postuluje, że „Zniewolony Umyst należy do dzieł szczególnie narażonych na zniekształcający odbiór. Dzieje się tak za sprawą świata przedstawionego w tym utworze, którego większość składników możemy odnieść wprost do konkretnej, niezawoalowanej rzeczywistości" ${ }^{36}$. Porównywalna sytuacja ma miejsce w przypadku Rodzinnej Europy - książce silnie osadzonej na faktach historycznych. Czytelnik instynktownie reaguje na wzmiankowane informacje, a rodzaj tych odpowiedzi podyktowany jest indywidualnym wyobrażeniem sytuacji geopolitycznej opisywanego regionu, który w przypadku anglojęzycznego czytelnika uwalania go od lokalnych uwarunkowań.

34 Tegoż, Native Realm. A Search for Self-Definition, tłum. C.S. Leach, Penguin Books, London 1968/1988, s. 16.

35 Rolę tę w tym rejonie Europy przejęła carska Rosja.

36 D. Pawelec, „Zniewolony Umyst” jako parabola, [w:] C. Miłosz, Zniewolony Umyst, Krajowa Agencja Wydawnicza, Kraków 1953/1989, s. 5. 
Jak widzimy, mimo usilnych starań zobiektywizowania problemu, Miłosz nie jest w stanie wniknąć w ludzkie stereotypy głęboko zakorzenione w narodowej tożsamości historycznej. Zwrot dotyczący osób „importowanych dla celów administracji” 37 powoduje wypłynięcie wielu skojarzeń zależnych od indywidualnych doświadczeń i wykształcenia czytelnika, a skupiających się wokół prób rusyfikacji Polski. Zwykły amerykański/angielski odbiorca ma nikłe szanse na rozpoznanie wagi powyższego fragmentu, nie będzie też świadomy trudów i wyrzeczeń, jakie Polacy podjęli, aby ofiarnie bronić polszczyzny przed rusyfikacją. Polski czytelnik instynktownie uruchamia listę skojarzeń i faktów, dowodzących zaangażowaniu $\mathrm{w}$ walce przeciw usankcjonowaniu języka rosyjskiego jako urzędowego. Niebagatelną rolę w tym zakresie odegrała społeczność literacka i zjawisko samizdatu - podziemnych, niezależnych oficyn wydawniczych, zwalczających cenzurę. Co ciekawe, przyjmuje się, że zjawisko nielegalnego kolportażu literatury, jak często mówiono, ma swoje źródło, paradoksalnie, w Rosji, gdzie niejaki „Głazkow już w latach czterdziestych przepisywał swoje wiersze na maszynie, spinał zapisane kartki w małe książeczki, a na pierwszej stronie dodawał podpis: "samsiebiaizdat«, następnie gotowe tomiki rozdawał bliskim i znajomym"38. Popularyzacja i spontaniczna aktywność podziemnych wydawnictw definiuje sytuację polskiego pisarza publikującego w kraju Europy Wschodniej i jest nieporównywalna do warunków wydawniczych panujących w Europie Zachodniej. Miłosz odważnie komentował ten fakt w osławionym już przez długie lata krytyki artykule o wymownym tytule Nie: „pisarze w krajach Zachodu nie mogą mieć pojęcia o opiece, jaką zapewniają ich kolegom państwa rządzone według zasad leninizmu-stalinizmu"39. Opublikowany po raz pierwszy w 1951 roku na łamach „Kultury” artykuł wywołał prawdziwą burzę w kręgach polskiej inteligencji i uruchomił lawinę oskarżeń i kalumnii wymierzonych w pisarza, co w efekcie miało doniosły wpływ na jego marginalizację i ostateczną emigrację. Jednak Miłosz nie mylił się i parafrazując słowa autora, można stwierdzić, że kondycja angielskiej/amerykańskiej literatury nigdy nie nosiła tak ewidentnego piętna historycznego w skali widocznej w krajach tzw. Wschodu. Taka sytuacja miała dwa wymiary - gromadziła literatów pod sztandarem walki z okupantem, jednocześnie boleśnie dzieląc naród licytujący się (właściwie do dziś) polskością. Przytoczone fakty mówią wiele na temat tożsamości nie tylko narodowej, lecz także osobistej, dokumentują bowiem silną integralność tej części ludzkości obecną na wielu płaszczyznach nie-

37 Tegoż, Rodzinna Europa, dz. cyt., s. 23.

38 M. Wójciak, Enklawy wolności, Universitas, Kraków 2010, s. 41.

39 J. Giedroyc, C. Miłosz, Listy 1952-1963, Czytelnik, Warszawa 2008, s. 718. 
osiągalnych dla czytelników tłumaczenia Rodzinnej Europy. Czytelnik angielski/amerykański zapewne dostrzeże zarysowany problem, umiejscowi go w czasie i przestrzeni historycznej, jednakże jego perspektywa, zarówno geopolityczna, jak i historyczna, nie pozwoli mu na odczytanie treści zawartych między wierszami.

Aby zaznaczyć rozmiar problemu, przytoczmy inny fragment Rodzinnej Europy oraz jego tłumaczenie. Fragment pochodzi z rozdziału pt. Miasto młodości:

Polska jak ją widzę dzisiaj, miała teatry lepiej zorganizowane niż wiele krajów tzw. zachodnich. W przeciwieństwie do trup tworzonych dla odegrania jednej sztuki, powszechnie uznawano zasadę teatru repertuarowego, pojmując pracę reżysera i aktora jako rodzaj służby społecznej ${ }^{40}$.

Poland as I look at it in retrospect, had better organized theaters than many "Western" countries. Instead of casts created to perform in one play, the principle of repertory theater was universally recognized and the work of director and actor was regarded as a kind of service to society ${ }^{41}$.

Fragment ten ilustruje gloryfikujący stosunek Miłosza do jakości polskiej sceny teatralnej. Warto tu jednak zwrócić uwagę na słowa zamykające cytat, które między wierszami niosą pewien ładunek emocjonalny nieczytelny dla anglojęzycznych odbiorców. W czasie drugiej wojny światowej, a także w okresie komunizmu, teatr polski imitował rolę samizda$t u$. Było to miejsce, gdzie potajemnie odgrywano polskie sztuki, oficjalnie zakazane, odpowiednio przez Niemców, a potem Rosjan. Ówczesne programy przedstawień uwzględniały przede wszystkim literaturę o głębokim, wręcz dydaktycznym przesłaniu, wypełnione zatem były patriotycznymi symbolami. Relacja między literaturą a teatrem osadzała się więc w mocnej tonacji narodowościowej, by nie rzec, nacjonalistycznej. Symbole patriotyczne, w sytuacji zagrożenia niepodległości, miały doniosły wpływ na ówczesną inteligencję, która osiągnęła do perfekcji sztukę działalności konspiratorskiej. Teatr stanowił także miejsce spotkań, gdzie wolna myśl mogła znaleźć ujście. Miłosz podkreśla jakość wystawianych sztuk, ich różnorodność i pewną konsekwencję w doborze repertuaru. Autor konkluduje: „poza kinem i teatrem równoległość w czasie utrzymywały książki" 42 i to zdanie unaocznia czytelnikom pozycję Polski/ Wschodu na świecie.

${ }^{40}$ C. Miłosz, Rodzinna Europa, dz. cyt., s. 63.

41 Powyższy zapis bibliograficzny odnosi się do reedycji Native Realm. A Search for Self-Definition wydanej w 1988 roku przez wydawnictwo Penguin Books i stosowany jest w dalszej części artykułu. C. Miłosz, Native Realm. A Search for Self-Definition, dz. cyt., s. 60 .

${ }^{42}$ C. Miłosz, Rodzinna Europa, dz. cyt., s. 64. 
Rozdźwięk kulturalny między Wschodem a Zachodem podyktowany odmiennymi doświadczeniami ilustruje problem Żydów. Miłosz, wywodzący się z obszaru, gdzie kwestia żydowska została wręcz upolityczniona, podnosi temat wyjątkowo ostrożnie:

O Żydach piszę z trudem, bo trzeba niemałego wysiłku, żeby oddzielić tamte napięcia od jednej z największych tragedii, jakie zdarzyły się w historii: wymordowania przez nazich około trzech milionów polskich obywateli, zaliczonych do grupy „niearyjskiej”. Jako naoczny świadek zbrodni ludobójstwa, a tym samym pozbawiony luksusu niewinności, jestem skłonny do oskarżeń rzucanych sobie i innym ${ }^{43}$.

\section{W tłumaczeniu czytamy:}

It is hard for me to write about the Jews, because no small effort is demanded if one is to distinguish these prewar tensions from one of the greatest tragedies of history: the slaughter of some three million "non-Aryan" Polish citizens by the Nazis. As an eyewitness to the crime of genocide, and therefore deprived of the luxury of innocence, I am prone to agree with the accusations brought against myself and others ${ }^{44}$.

Zacytowane fragmenty obrazują skomplikowaną naturę relacji wewnątrzpaństwowych obecną między Polakami i Żydami. Miłosz wyraża tu dwojaki rodzaj emocji: autor czuje wstyd i zażenowanie wynikajace z częściowej winy, jaką ponoszą Polacy za Holokaust, jednocześnie wydaje się przepełniony złością skierowaną na siebie i naród za brak stanowczej inicjatywy w ratowaniu Żydów. Implikuje autor narodową winę, kolektywną odpowiedzialność za ludobójstwo odbywające się na rodzinnej ziemi. Zawiłość problemu nie jest do końca jasna nawet dla Polaków, czego dowodem są niektóre kręgi kościelne i polityczne, w dalszym ciągu wykorzystujące antysemityzm do osiągnięcia partykularnych celów środowiskowych. Nie dzieje się to bez powodu, społeczeństwo zostało podzielone w tej kwestii, czego rezultatem jest podatny grunt dla antysemickich oskarżeń.

Czytelnikowi tłumaczenia jawi się Miłosz jako oskarżyciel lub wręcz pokutnik. Rok wydania Native Realm - 1968 - zbiega się z zimną wojną i nie jest to dobry okres na rozliczenia czy też publiczne konfesje. Sprawa obozów koncentracyjnych do dziś budzi niemałe kontrowersje w świecie Europy Zachodniej. Znane są sytuacje, gdy nieświadomi rzecznicy organizacji o różnorakiej proweniencji stosują skrót myślowy, mówiąc o „polskich obozach koncentracyjnych”. Tworzy się zniekształcony obraz pro-

43 Tamże, s. 100. Emfaza dodana.

${ }^{44}$ C. Miłosz, Native Realm. A Search for Self-Definition, dz. cyt., s. 105. Emfaza dodana. 
blemu, dziś masy społeczne nie są zainteresowane rewizjonizmem, jednakowoż wszechobecny przekaz medialny utrwala pewne bolesne stereotypy i przeciętny czytelnik angielski/amerykański napotka w tłumaczeniu Rodzinnej Europy liczne pojęcia, które nie stanowią dla niego realnego odniesienia, poza mglistym wyobrażeniem problemu. Tłumaczka wydaje się świadoma olbrzymich różnic percepcyjnych w tym zakresie, dlatego też precyzuje, o jakie tamte napięcia chodzi, dodając informację lokalizującą problem w czasie - prewar tensions.

W świetle powyższych rozważań należy stwierdzić kilka istotnych faktów. Po pierwsze, Rodzinna Europa jest pozycją skierowaną przede wszystkim do czytelnika zachodnioeuropejskiego - tłumaczy to powściągliwość Czesława Miłosza, świadomego wagi przedsięwzięcia i specyfiki Europejczyków państw zachodnich. Po drugie, słowiańska dusza autora i głębokie kulturalno-historyczne zakorzenienie w Słowiańszczyźnie, wyznacza granice recepcyjne informacji zawartych między wierszami w przypadku czytelnika zachodnioeuropejskiego. I wreszcie po trzecie, angielskie tłumaczenie Rodzinnej Europy proponuje wizje i historię Miłosza przełożone bardzo poprawnie, aczkolwiek różnice kulturalno-historyczne i w efekcie światopoglądowe między „dwiema Europami” tworzą barierę zamykającą przestrzeń międzywierszową dla czytelników przekładu.

Tekst ten niech zamknie cytat pochodzący z korespondencji prowadzonej między Zbigniewem Herbertem a Czesławem Miłoszem, gdzie Herbert, w jednym z listów, z rozbrajającą szczerością wyznaje: „czytałem po francusku Rodzinna Europę. Świetnie przełożona. Mam nadzieję że te chamy Francuzy coś trochę zrozumieją"45.

45 Z. Herbert, C. Miłosz, Korespondencja, dz. cyt., s. 41. 